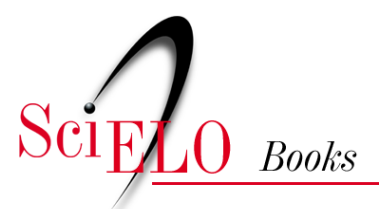

\title{
Para uma teoria do movimento sanitário
}

\author{
Sonia Fleury
}

\section{SciELO Books / SciELO Livros / SciELO Libros}

FLEURY, S. Para uma teoria do movimento sanitário. In: AROUCA, S. O dilema preventivista: contribuição para a compreensão e crítica da medicina preventiva [online]. Rio de Janeiro: Editora FIOCRUZ, 2003, pp. 243-247. ISBN: 978-85-7541-610-5. Available from: doi:

10.7476/9788575416105.0021. Also available in ePUB from: http://books.scielo.org/id/q7gtd/epub/arouca-9788575416105.epub

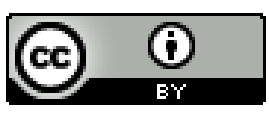

All the contents of this work, except where otherwise noted, is licensed under a Creative Commons Attribution $\underline{4.0 \text { International license. }}$

Todo o conteúdo deste trabalho, exceto quando houver ressalva, é publicado sob a licença Creative Commons Atribição 4.0. 


\section{PARA UMa TeORIA Do MOVIMENTO SANITÁRIo}

Sonia Fleury ${ }^{1}$

Ao desvendar as articulações entre Medicina e Sociedade, Sérgio Arouca expóe o dilema da Medicina Preventiva entendido como uma leitura liberal e civil desse campo de tensões, materializando-se como prática discursiva, ideológica e empírico-experimental, que, no entanto, não alcança desenvolver seja uma prática teórica seja uma prática política, que possibilitariam condições de produção das mudanças desejadas. A viabilidade do projeto preventivista implica a superação dos seus limites liberais que pretendem redefinir as responsabilidades do médico por meio da inculcação de uma preocupação social, mantendo, no entanto, preservadas a natureza do seu trabalho, a organização da prática médica e a estrutura social. Transcender esses limites restritos à alteração dos comportamentos dos profissionais requer formular uma teoria que dê conta das reais determinações da crise no setor saúde e caminhar em direção a uma prática política que represente um movimento de transformação conjunta do trabalho médico, da consciência sanitária, da produção das condições de saúde e doença, do conhecimento e das políticas de saúde. Com essa análise Sérgio Arouca lança as bases teóricas para a organização do movimento pela Reforma Sanitária, que floresceu e tornou-se uma realidade política a partir dos anos 80 .

Para analisar as relações entre Medicina e Sociedade o autor toma a unidade mais simples a ser considerada no interior da Medicina, ou seja, o cuidado médico, a relação entre duas pessoas, uma cujo sofrimento se ma-

1 Doutora em Ciência Política; professora da Escola Brasileira de Administração Pública e de Empresas da Fundação Getúlio Vargas; pesquisadora da Fundação Oswaldo Cruz e membro do Conselho do Desenvolvimento Econômico e Social. 
nifesta como necessidade de cuidado por parte de outra, que é socialmente determinada e legitimada para tanto.

Essa simples relação entre duas pessoas está prenhe de significações sociais, na medida em que implica a existência da concentração do saber em mãos de um grupo profissional, ao qual é atribuído o direito de exercício dessa prática, como parte da divisão técnica do trabalho. O sofrimento e o conhecimento se encontram em uma relação de troca. No entanto, o que se troca não é o conhecimento, mas o cuidado, que é a forma instrumental desse conhecimento monopolizado.

O cuidado médico representa uma dupla característica, a primeira de ser um processo de trabalho que tem como objetivo a intervenção em valores vitais (biológicos e psicológicos) e a segunda, ao atender necessidades humanas, de ser uma unidade de troca à qual é atribuída, social e historicamente, um valor.

Com essa análise, Arouca lançou as luzes para que pudéssemos identificar a especificidade das políticas sociais, que residem, exatamente, nessa relação singular entre dois sujeitos sociais. Uma relação que envolve uma troca e também um consumo de mercadorias, uma base técnico-científica, um conjunto de valores e uma relação de poder. É exatamente essa especificidade que nos permite pensar as políticas sociais, representadas nessa relação entre dois agentes sociais em um dado contexto histórico, tanto como uma possível reificação da estrutura de dominação como, ao contrário, a possibilidade de uma transformação dessa estrutura social.

Ao apontar a incidência do cuidado sobre valores vitais, que definem biológica e socialmente as necessidades humanas, podemos divisar uma das principais estratégias que caracterizou a Reforma Sanitária Brasileira, qual seja, a construção de coalizões amplas em torno de valores que transcendem o conteúdo meramente classista. Sem negar a determinação do trabalho médico pela estrutura social no qual ele se realiza, é necessário compreender as necessidades sociais como expressão da contradição entre o vital e o social, definindo aí os limites e possibilidades das práticas sociais.

Arouca inaugura o campo de estudos da chamada economia da saúde ao identificar as relações entre Medicina e produção capitalista, fundadas na capacidade do cuidado permitir a elevação da produtividade do trabalho, na redução das desigualdades e das tensões sociais, na sua incidência sobre a produção de valores (valores de uso para os detentores da força de 
trabalho e valores de troca para os capitalistas), na capacidade de determinação de uma normatividade social. Fundamentalmente, o autor rompe com a tradição marxista que considerava o trabalho em saúde como trabalho não produtivo, para entendê-lo como parte de um trabalho socialmente combinado, ou seja, como parte do processo de geração, produção e consumo de mercadorias. Sendo nessa simples relação de troca entre médico e paciente que são consumidas as mercadorias industriais como os equipamentos e os medicamentos, o cuidado médico passa a ser um setor de consumo produtivo, cada vez mais determinado pela dinâmica de acumulação dos setores industriais.

A separação entre técnica e conhecimento é necessária para compreensão da inserção da medicina no circuito da produção e consumo capitalistas. É a técnica, em sua dimensão instrumental, que permite a distribuição, troca e consumo dos bens industriais, mas que, por outro lado, requer a mediação do profissional, detentor de um conhecimento específico, para que a realização do valor das mercadorias se complete.

Outra articulação entre Medicina e produção diz respeito ao cuidado que se dirige a uma classe social, como os trabalhadores. Medicina do Trabalho, programas de Saúde Pública para o grupo materno-infantil, programas de Medicina Previdenciária etc. são todas medidas voltadas para a reprodução e recuperação da força de trabalho. Participam da organização do processo produtivo, da manutenção das condições de consumo da força de trabalho e da socialização dos custos de sua recuperação.

Ao analisar as relações entre Medicina e economia, Arouca assinala a importância do processo de assalariamento médico, fenômeno que recéminiciava-se entre nós, associando-o à construção do complexo médico-industrial nesse cenário.

Sua hipótese sobre a determinação econômica da organização social da prática médica abriu caminho para os múltiplos estudos que foram desenvolvidos com vistas a entender o que se chamou entre nós o "Complexo Médico Previdenciário". Através desses estudos resgatava-se o nível organizacional como objeto da investigação das ciências sociais aplicadas em saúde, buscando entendê-lo como uma das articulações possíveis entre uma prática técnica com suas determinações econômicas, sociais e culturais. Organizações e instituições deixam de ser vistas desde um paradigma de busca de racionalidade e eficiência para serem compreendidas como espaço contraditório de materialização da luta de classes. 
No capitalismo monopolista do século Xx já não há espaço para as práticas liberais que possibilitaram o nascimento da clínica, pois a mercadoria se universaliza e atinge setores sociais anteriormente alheios à dinâmica da acumulação capitalista. A medicina desenvolve-se, pois, como organização da produção, distribuição e consumo de cuidados médicos. É necessário que esses setores sejam controlados e o trabalho ganhe a racionalidade das práticas produtivas, submetendo os processos de trabalho a essa lógica mercantil, na qual os produtores perdem o controle sobre o processo de trabalho. Nesse ponto, Arouca brilhantemente assinala as grandes transformações que caracterizariam os processos de privatização, o ocaso do trabalho liberal com o acelerado processo de assalariamento e, finalmente, o consumo de bens sociais. No entanto, esse processo de ampliação do regime do capital aos setores sociais acarretaria múltiplos conflitos que passamos a vivenciar.

Ao afirmar que a sociedade capitalista não é capaz de satisfazer as necessidades que ela própria cria o autor assinala: "a sociedade capitalista cria dois tipos de necessidades: o primeiro, que são aqueles conjuntos de necessidades que devem se constituir em consumo para a produção industrial, permitindo a realização da mais-valia, e o segundo, como sendo aquele de necessidades decorrentes do próprio funcionamento do sistema, como as doenças carenciais, mentais, a violência, ocupacionais etc. Assim, a produção cria não somente o consumo produtivo, mas também uma necessidade que não se realiza, ou seja, que não consome nem é consumida no processo produtivo".

Apesar de afirmar-se como socialmente igualitária e universal, a sociedade capitalista, em especial as periféricas, acentuam as contradições entre o discurso igualitário dos direitos sociais e as necessidades sociais não atendidas.

Nesse contexto, o autor vê no papel do Estado uma possibilidade de rearticulação do setor saúde, através da reorganização do trabalho médico e da utilização do seu poder político para regular e controlar as indústrias do setor. Essa proposta reformista supõe o rompimento com a origem liberal e civil do projeto da Medicina Preventiva, rumo a um movimento de mudança, a uma Reforma Sanitária.

Arouca fala então da necessidade de mudança e das limitações da Medicina Preventiva, que não alcança transcender o mundo das representa- 
ções. Para isso, é necessário desenvolver uma prática teórica que permita analisar as determinações da crise do setor saúde e uma prática política que leve às mudanças necessárias. Não chegou a usar a expressão Reforma Sanitária neste capítulo - que só passaria a ser usada na década seguinte -, mas havia elaborado os fundamentos para uma teoria do Movimento Sanitário que, liderado por ele, desfraldou a bandeira da Reforma. AXÉ! 